\title{
THE IMPACT OF THE INITIAL STANCE POSITION ON LOWER LIMB JOINT KINETICS IN THE TAEKWONDO ROUNDHOUSE KICK
}

\author{
Daniel Jandačka ${ }^{1, *}$, Isaac Estevan², Miroslav Janura ${ }^{3}$, Coral Falco²
}

\author{
${ }^{l}$ Human Motion Diagnostic Center, University of Ostrava, Ostrava, Czech Republic \\ ${ }^{2}$ Department of Applied Sciences in Physical Activity and Management, Universidad Católica de Valencia "San Vicente \\ Mártir", Torrent, Spain \\ ${ }^{3}$ Faculty of Physical Culture, Palacký University, Olomouc, Czech Republic
}

Submitted in July, 2013

\begin{abstract}
BACKGROUND: To achieve good performance, taekwondo athletes should optimize the stance position of the foot on the ground.

OBJECTIVE: The aim of this study is to compare generated net joint power (hip, knee and ankle) during stance phase, magnitude of peak foot velocity of the attacking lower extremity and execution stance time produced from three stance positions (forward " 0 ", diagonal " $45^{\circ}$ ", orthogonal " $90^{\circ}$ ") in the taekwondo roundhouse kick.

METHODS: Ten taekwondo athletes participated in the study; their experience of practicing taekwondo ranged between $13.8 \pm 5.8$ years. The kinetics and kinematics of the athletes' movement during the roundhouse kick were recorded. The execution stance time and the magnitude of peak foot velocity were determined. The net joint power of the kicking lower extremity during the stance phase was calculated using the inverse dynamics method. Then the peak net joint power was determined.

RESULTS: The analysis of variance for repeated measures showed that there is a significant main effect of the stance position on the peak net hip joint power in the three planes. In addition, the stance position does not affect the magnitude of the peak foot velocity of the kicking lower extremity and execution stance time.

CONCLUSIONS: The necessity to produce a higher net hip joint power in the stance phase of the roundhouse kick from the position when the feet are placed orthogonal to the target of the kick, compared with the execution of the kick from the forward or diagonal position, must be taken into account for purposes of rationalizing strength training of taekwondo athletes or for selecting the technique of the roundhouse kick.
\end{abstract}

Keywords: Power training, inverse dynamics, biomechanics, stance position.

\section{INTRODUCTION}

Maximum power movements are common in combat sports (Melhim, 2001). In taekwondo, the most frequent movement is kicking; the fastest type of kick is the roundhouse kick (Pieter \& Pieter, 1995). This kick is developed in a shorter time than any other kick thanks to the high coordination of movement from the individual joints of the lower extremities (Kim, Kim, $\&$ Im, 2011). As an explosive task, a kick requires the kicker to develop a powerful movement, achieving a high performance similar to a sprint start (Mero, 1988). During taekwondo training and combats, athletes adopt a specific position called guard position cha-

\footnotetext{
* Address for correspondence: Daniel Jandačka, Human Motion Diagnostic Center, University of Ostrava, Varenská 40a, 70200 Ostrava, Czech Republic. E-mail: daniel.jandacka@osu.cz
}

racterized by stances with their legs front and back along the direction of attack (Kim, Kwon, Yenuga, \& Kwon, 2010). This guard position allows athletes to get ready for attacking and counterattacking. The stance phase (the period of time that accounts attacking foot in contact with the floor prior to take off) maintaining the guard position is one of the most important phases necessary to produce the best kick (Pozo, Bastien, \& Dierick, 2011). During the kick, the short period of the execution stance time (the period of time between the instants of reaction and instant at which the kicking foot left the floor) and the high magnitude of the peak foot velocity place great demands on the production of the maximum muscle power in the roundhouse kick. Great magnitude of the peak foot velocity in a short period of execution stance time can only be achieved when the joints generate sufficient net power (Kraemer \& Newton, 2000).

Net joint power has been defined as the product of the joint moment and joint angular velocity (Hamill 
\& Selbie, 2004). Peak power represents the greatest net power during a single movement, developed with the aim of achieving the highest possible magnitude of peak foot velocity (Kraemer \& Newton, 2000). The calculation of net joint power during stance derived from inverse dynamics calculations has been successfully used to indirectly determine the positive or negative action of the muscle groups (flexors or extensors) that cross specific joints during a sprint start (Charalambous, Irwin, Bezodis, \& Kerwin, 2012). Therefore inverse dynamics could provide information on the specificity of movement tasks in taekwondo.

In pursuit of excellence (maximal performance), and prior to initiating the movement athletes should optimize the position of the lower limbs on the ground (Mero, Kuitunen, Harland, Kyrolainen, \& Komi, 2006). That is, coaches and athletes should look for the best foot position which allows them to get the best performance in terms of the maximal power generated by the athlete. To the authors' knowledge, currently there has not been any published research on lower extremity power in taekwondo. A similar motor task to a kick start in taekwondo is sprinter's start from blocks. Mero et al. (2006) found that in a sprinter's starting position, the lower the block angle, the lower power of plantar flexors. They also noted the importance of the role played by the hip extensors at the beginning of the sprint. In taekwondo, the stance position has been highlighted as a factor that can influence the kinematics of taekwondo athletes' kicking (Kim, Kwon, Yenuga, \& Kwon, 2010), especially in the initial phase, when the rear lower extremity is in contact with the ground (Estevan, Jandacka, Farana, \& Falco, 2012). Taekwondo athletes often choose a different initial stance position of the feet, which may be rotated by $0^{\circ}, 45^{\circ}$ or $90^{\circ}$ with respect to the connecting line between the athlete and the target of the kick (Estevan, Jandačka, \& Falco, 2011). One pilot study has determined that when the initial foot's position is orthogonal $\left(90^{\circ}\right)$, the total response time of the kick is longer than when the foots are positioned in the forward $\left(0^{\circ}\right)$ and diagonal $\left(45^{\circ}\right)$ positions (Estevan, Falco, \& Jandačka, 2011). Thus, the analysis of the net joint power (ankle, knee and hip) in the roundhouse kick according to the stance position could help to clarify the effect of different feet orientations on the athletes' performance.

The aim of this study is to compare the generated net joint power (hip, knee and ankle) during the stance phase, the magnitude of peak foot velocity of the attacking lower extremity and the execution stance time produced from three stance positions (forward " 0 " ", diagonal " $45^{\circ}$ ", orthogonal " $90^{\circ}$ ") in the taekwondo roundhouse kick. Because the initial stance position appears to affect thigh kinematics (Estevan et al., 2011), the authors of this study assume that the stance position will mainly affect the net hip joint power during the contact of the lower extremity with the ground. This study will allow coaches and taekwondo athletes to understand the net joint power generation during the roundhouse kicks and will also help them to orient muscle power training specifically.

\section{METHODS}

\section{Participants}

Ten taekwondo athletes participated in the study (five males and five females, five left-footed and five rightfooted); the mean \pm standard deviation in their experience of practicing taekwondo was $13.8 \pm 5.8$ years. The mean age of the participants was $25.4 \pm 5.0$ years; their mean weight was $72.7 \pm 15.4 \mathrm{~kg}$ and their mean height was $1.75 \pm 0.10 \mathrm{~m}$. All athletes have experience in taekwondo of at least 6 years, are of black belt level and train for at least 3 hours/week. None of the athletes had a history of injury within the six months before measurements. Ethics approval was secured from the principal author's University Ethics and Research Committee and all participants signed an informed consent form prior to data collection.

\section{Experimental settings}

Participants stood with each lower extremity on the two force plates; those were located on the ground and measured the reaction forces (Kistler 9286AA, Switzerland). The kinematics of the taekwondo athletes' movement during the roundhouse kick were recorded using eight infrared cameras (Qualisys Oqus, Sweden) with a frequency of $247 \mathrm{~Hz}$. Cameras were located around the force plates and the target (a suspended foam ball). A light-emitting diode (LED) was placed on the target; it lit up when the measuring system of the synchronized force plates was launched and the recording of the movement began.

\section{Protocol}

When the athletes had warmed up, 26 retro-reflective markers were placed on their bodies. The calibration markers were placed bilaterally on the lateral and medial malleolus, the medial and lateral femoral epicondyles, the greater trochanter of the femur, and on the feet over the first and fifth metatarsal heads. The tracking markers were positioned and securely affixed to define the target, the trunk (acromion), the tenth thoracic vertebra, the chondral projection of the sternum, the iliac spine, the posterior superior iliac crest, the anterior superior iliac crest and the posterior calcaneus. Additionally, hard light-weight plates with four tracking markers were placed on the thigh and shin and two other tracking markers were placed on the calcaneus. After taking a static calibration record in the basic 
anatomical position (to define the segment dimensions and the relations between the calibration and tracking markers), the calibration markers were removed from the athletes' bodies. Subsequently, each participant placed his/her feet (barefoot) on the prepared force plates; the kick was executed with the rear lower extremity. The stance position of the feet was established by the visible axes positioned on the force plates and marking the angles of $0^{\circ}, 45^{\circ}$ and $90^{\circ}$ to the line connecting the athlete and the target (Estevan et al., 2011). Degrees in each stance position refers to the disposition of the feet with respect to the target; that is, when $0^{\circ}$ stance position was established athletes' feet oriented approximately forward toward the target. When $45^{\circ}$ stance position was established athletes stood with their feet approximately in a diagonal direction $\left(45^{\circ}\right)$ with respect to the target, and lastly, for $90^{\circ}$ stance position, athletes stood with their feet approximately in an orthogonal direction $\left(90^{\circ}\right)$ with respect to the target (Estevan, Jandačka, \& Falco, 2013). The distribution of the magnitude of GRF (\% body weight) in the force plates from the $0^{\circ}$ stance position was $4 \%$ of body weight higher on the front foot; from the $45^{\circ}$ stance position the magnitude of GRF was equally distributed; from the $90^{\circ}$ stance position the magnitude of GRF was $4 \%$ of body weight higher on the rear foot. Each participant's preferred target distance was used as the target height and execution distance (Kim et al., 2010). Prior to the measurements, the athletes executed two warm-up roundhouse kicks from each stance position. Finally, they performed 15 kicks, i.e. five trials in each of the three stance positions in a randomized order. Each trial started when the LED lit up. The athletes were instructed to react and hit the target as fast as possible.

\section{Data analysis}

The retro-reflective marker data were processed using Visual 3D software (C-motion, USA). The lower extremity segments were modelled as a frustum of cones, while the torso and pelvis were modelled as a cylinder (Hanavan, 1964). The instant at which the LED switched on was marked, and the instant at which the kicking lower extremity reaction force achieved $1 \%$ of the participants' body weight was marked. Additionally, the instant at which the kicking lower extremity left the force plate and the reaction force dropped below $1 \%$ of the participants' body weight was marked. The stance phase was determined as the time between the instants at which the LED switched on and the kicking foot left the force plate. The execution stance time was determined as the time between the instants at which the ground reaction force achieved $1 \%$ of the body weight and the kicking foot left the force plate. The recorded data of all the marker positions were filtered using a low-pass filter with a cut-off frequency of $12 \mathrm{~Hz}$; the analogue signal of the force plates was filtered using a low-pass filter with a frequency of $50 \mathrm{~Hz}$. The net joint power was calculated using the inverse dynamics method (Hamill \& Selbie, 2004) and expressed in the local coordinate system of the proximal segment (Grood \& Suntay, 1983). The net power of the ankle, knee and hip joints was calculated as a product of the angular velocity and the instantaneous net joint moment. Subsequently, the net positive peak power in the stance position of the kicking lower extremity for the ankle, knee and hip joint in the sagittal, frontal and transversal planes was computed. To understand what muscle groups and what joint action generated the positive power output, we created graphs showing the dependence (Figures 1-3) of the net joint moment of force, angular velocity and net joint power on the relative duration of the stance phase (\% of the stance phase). Each participant was represented by a mean signal of the five trials in each of the three examined situations. The instantaneous net joint moment and the angular velocity in the transversal and frontal plane were multiplied by -1 in each instant in left-footed participants. This sign correction was carried out in order that both quantities would express anatomically the same information as in the case of the participants kicking with their right lower extremity. All values of the net joint moments and powers were standardized using body mass. Moreover, the peak magnitude of foot velocity was expressed in the swing phase prior to the impact in the global coordinate system of the laboratory.

\section{Statistical analysis}

The statistical analysis was performed using SPSS 17 (SPSS Inc., Chicago, IL). All variables were normally distributed (Kolmogorov-Smirnov test). The reliability of measurement was assessed using the intraclass correlation coefficient (ICC) (Hopkins, 2000). A one-way analysis of variance for repeated measure (ANOVA) with stance position as a factor (three levels $-0^{\circ}, 45^{\circ}$ and $90^{\circ}$ ) was used to compare the net power in the ankle, knee and hip joints. In addition, a one-way analysis of variance for repeated measure (ANOVA) was used to compare the magnitude of peak foot velocity and execution stance time according to the stance position. If Mauchly's test of sphericity was significant, Greenhouse-Geisser corrections were used. Subsequent paired comparisons were performed using Bonferroni's correction. The effect size of the initial stance position on the dependent variable was evaluated using the partial Eta square index (Cohen, 1973). As we used the single-factor analysis of variance, we considered the value of partial $\eta^{2}<.099$ to have a trivial effect, partial $\eta^{2}=.0099-.0588$ to have a small effect, partial $\eta^{2}=.0588-.1379$ to have a medium effect, and partial 
$\eta^{2}>.1379$ to have a large effect (Cohen, 1988). The statistical power of the test (SP) was expressed according to Cohen (1962). The statistical significance for all tests was adjusted at $p<.05$.

\section{RESULTS}

The intraclass correlation coefficient (ICC) calculated from the five repeated measurements of the net ankle, knee and hip joint power in the sagittal plane achieved values between .85 and .94 and in the frontal and transversal planes achieved values between .70 and .90 . The ICC of the magnitude of foot velocity achieved values between .81 and .95 . The ICC of the execution stance time achieved values between .82 and .95 . The ICC of $>.70$ may be considered a satisfactory level of reliability of measurement (Hopkins, 2000).

The analysis of variance for repeated measures showed that there is a significant main effect of the stance position on the peak of the net hip joint power in the three planes - sagittal $(F=12.67, p=.00, d f=2$, partial $\eta^{2}=.575$ and $\left.\mathrm{SP}=0.98\right)$, frontal $(F=5.093$, $p=.02, d f=2$, partial $\eta^{2}=.361$ and $\left.\mathrm{SP}=0.80\right)$, and transversal $\left(F=9.680, p=.00, d f=2\right.$, partial $\eta^{2}=.518$ and $\mathrm{SP}=0.96)$. Subsequent Bonferroni paired comparisons showed that in the sagittal and frontal planes, the taekwondo athletes generated a higher the peak of the net hip joint power from the $90^{\circ}$ stance position than from the $45^{\circ}$ and $0^{\circ}$ stance positions $(p<.02)$.
Moreover, in the transversal plane, the athletes generated a higher peak of the net hip joint power from the $90^{\circ}$ stance position than from the $0^{\circ}$ stance position $(p<.01)$ (Table 1). The main effect of the stance position on the peak of the net ankle joint power and peak of the net knee joint power in the three analyzed planes was not significant $(p>.05)$. The main effect of the stance position on the execution stance time or on the magitude of the peak foot velocity prior to the impact was not significant $(p>.05)$.

\section{DISCUSSION}

As has been stated, the peak net power represents the greatest net power during a single movement developed with the aim of achieving the highest possible velocity during impact (Kraemer \& Newton, 2000). In the case of kicks, the initial stance phase could provide key information for developing optimum execution (Pozo, Bastien, \& Dierick, 2011). Figure 1 shows that there is an extension angular velocity in the hip joint at the instant of the peak net power generation in the sagittal plane, and at the same time the hip joint extensors develop the extensor moment of force from each of the examined stance positions. Moreover, in the frontal plane, the peak net hip joint power is generated by the hip joint adductors through the positive adduction moment of force at adduction angular velocity (Figure 2). In the transversal plane, positive peak power is mainly

Table 1

The mean and standard deviation of the peak generated net ankle, knee and hip joint power during the stance phase, the peak magnitude foot velocity and execution stance time, according to the initial stance position $(N=10)$

\begin{tabular}{lccc}
\hline & $0^{\circ}$ Stance Position & $45^{\circ}$ Stance Position & $90^{\circ}$ Stance Position \\
\hline Net hip power $\left(\mathrm{W} \cdot \mathrm{kg}^{-1}\right)$ & & & \\
Sagittal & $4.21 \pm 2.65^{\mathrm{a}}$ & $4.55 \pm 2.72^{\mathrm{b}}$ & $6.47 \pm 3.56^{\mathrm{ab}}$ \\
Frontal & $0.72 \pm 0.31^{\mathrm{a}}$ & $1.14 \pm 0.81^{\mathrm{b}}$ & $3.33 \pm 2.48^{\mathrm{ab}}$ \\
$\quad$ Transversal & $0.86 \pm 0.69^{\mathrm{a}}$ & $1.42 \pm 1.24$ & $1.72 \pm 1.09^{\mathrm{a}}$ \\
Net knee power $\left(\mathrm{W} \cdot \mathrm{kg}^{-1}\right)$ & & & \\
Sagittal & $2.53 \pm 2.54$ & $2.88 \pm 2.36$ & $3.54 \pm 2.34$ \\
Frontal & $0.48 \pm 0.33$ & $0.97 \pm 0.69$ & $1.46 \pm 1.19$ \\
Transversal & $0.51 \pm 0.27$ & $0.46 \pm 0.37$ & $0.62 \pm 0.57$ \\
Net ankle power $\left(\mathrm{W} \cdot \mathrm{kg}^{-1}\right)$ & & & \\
Sagittal & $6.56 \pm 2.40$ & $7.11 \pm 2.70$ & $0.45 \pm 0.32$ \\
Frontal & $0.37 \pm 0.28$ & $0.56 \pm 0.52$ & $0.50 \pm 0.36$ \\
Transversal & $0.30 \pm 0.18$ & $0.65 \pm 0.99$ & $11.98 \pm 1.15$ \\
Foot velocity $\left(\mathrm{m} \cdot \mathrm{s}^{-1}\right)$ & $11.82 \pm 1.40$ & $11.89 \pm 1.36$ & $360 \pm 78$ \\
Execution stance time $(\mathrm{ms})$ & $360 \pm 65$ & $361 \pm 79$ & \\
\hline
\end{tabular}

Note. Identical letters $\left({ }^{\mathrm{a}}\right.$ or $^{\mathrm{b}}$ ) to the right of the mean and standard deviations values denote significant differences $(p<.05)$. 

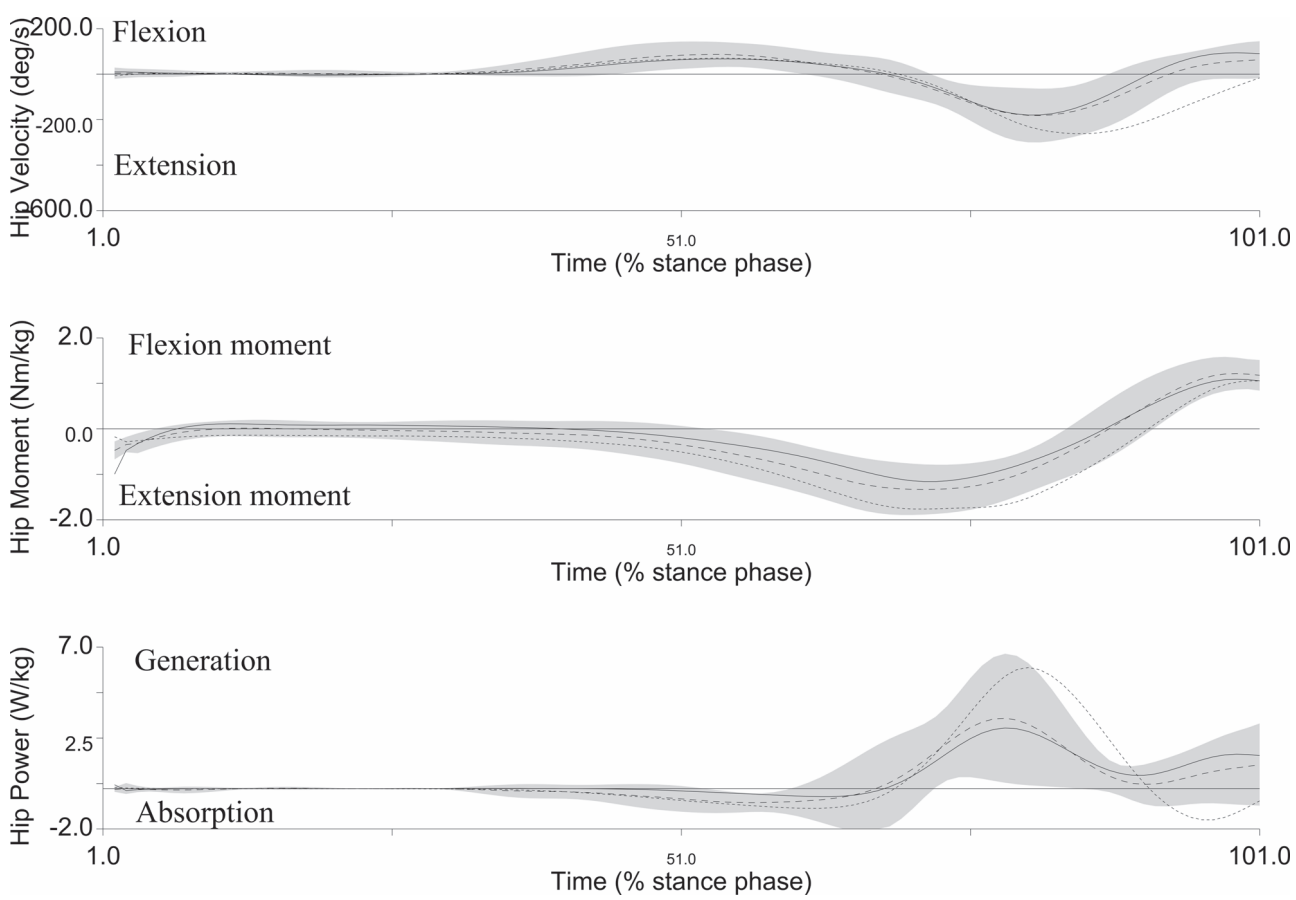

Figure 1. Mean of hip angular velocity, net hip moment of force and net hip joint power in the sagittal plane during the relative times of the three $\left(0^{\circ}, 45^{\circ}\right.$ and $\left.90^{\circ}\right)$ stance positions $(N=10)$. The solid line represents the mean during $0^{\circ}$, the dashed line during the $45^{\circ}$ stance position and the dotted line during the $90^{\circ}$ stance position. The solid area represents the standard deviation from the $45^{\circ}$ curve.
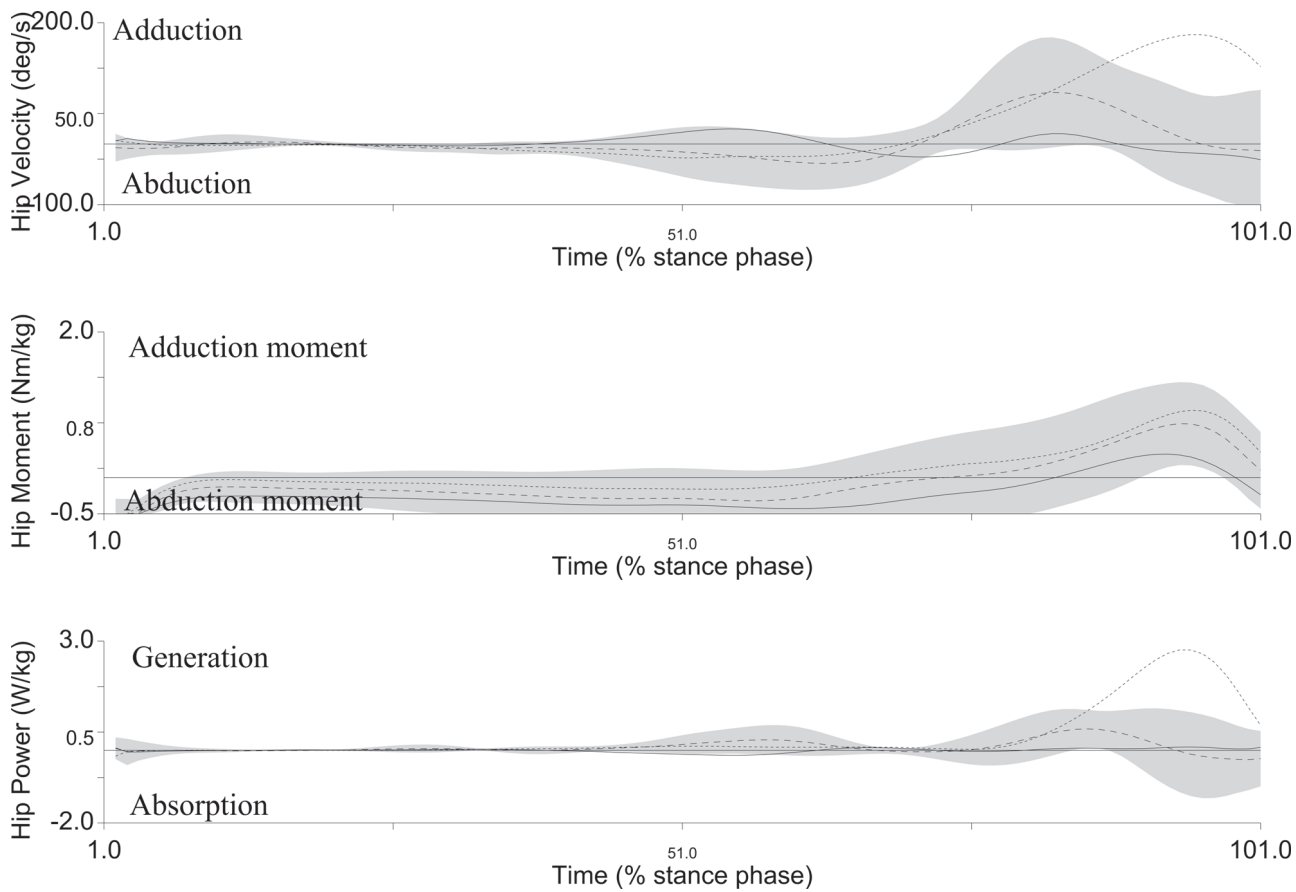

Figure 2. Mean of hip angular velocity, net hip moment of force and net hip joint power in the frontal plane during the relative times of the three $\left(0^{\circ}, 45^{\circ}\right.$ and $\left.90^{\circ}\right)$ stance positions $(N=10)$. The solid line represents the mean during $0^{\circ}$, the dashed line during the $45^{\circ}$ stance position and the dotted line during the $90^{\circ}$ stance position. The solid area represents the standard deviation from the $45^{\circ}$ curve. 
generated by the muscles that cause the moment of the external rotation of the hip joint (Figure 3 ). Our study provides specific and complementary information supporting the findings of Pozo et al. (2011), suggesting that coaches and taekwondo trainers should focus their peak power training on the muscle groups that cause the extension, adduction and external rotation of the hip joint in the stance position.

The hypothesis that the initial stance position has an effect on the peak of the generated net hip joint power has been confirmed. Muscles that create the movement of the hip joint must generate a higher net peak power from the $90^{\circ}$ initial stance position than from the $0^{\circ}$ and $45^{\circ}$ positions. Visual analysis of curves of interest shows that the reason for this difference in the sagittal, frontal and transversal planes could be the higher extension moment and extension angular velocity (Figure 1), the higher adduction moment and adduction angular velocity (Figure 2 ), and the higher external rotation moment (Figure 3 ) from the $90^{\circ}$ initial stance position than from the $0^{\circ}$ and $45^{\circ}$ positions. The higher angular velocity in the sagittal and frontal planes may be related to the different motor control of the agonist-antagonist muscles of the hip joint during the examined stance conditions. By contrast, the higher hip moment in the sagittal, frontal and transversal planes in the $90^{\circ}$ stance condition may be related to weight distribution on the feet (higher ground reaction force at the rear foot during $90^{\circ}$ than during $0^{\circ}$ and $45^{\circ}$ initial stance positions).

However, the performance (magnitude of the peak foot velocity of the kicking lower extremity) does not differ in relation to the initial stance position. Additionally, execution stance time was not affected by initial stance position. The similar execution stance time and the higher value of the net hip joint power curves from $90^{\circ}$ could imply that the kick from the $90^{\circ}$ stance position could be more demanding in terms of mechanical work than kicks from the $0^{\circ}$ and $45^{\circ}$ stance positions. Thus, it seems that in taekwondo the generation of higher power during the stance of the kick does not directly mean higher performance. In this sense, Estevan et al. (2011) found that athletes' performance from the $90^{\circ}$ stance position was lower than from the $0^{\circ}$ and $45^{\circ}$ stance positions. The implications of our results support Estevan et al. (2011) findings, namely that taekwondo athletes and coaches should avoid using orthogonal stance positions when athletes are fatigued because this stance position appears to cause the muscle work generation of the hip to be higher than from the diagonal or forward stance positions, and athletes are not able to attain higher performance than from the $0^{\circ}$ or $45^{\circ}$ stance position.

Regarding the data for the knee and ankle joints, the results showed that the peak net power is not affected by the initial stance position of the lower ex-
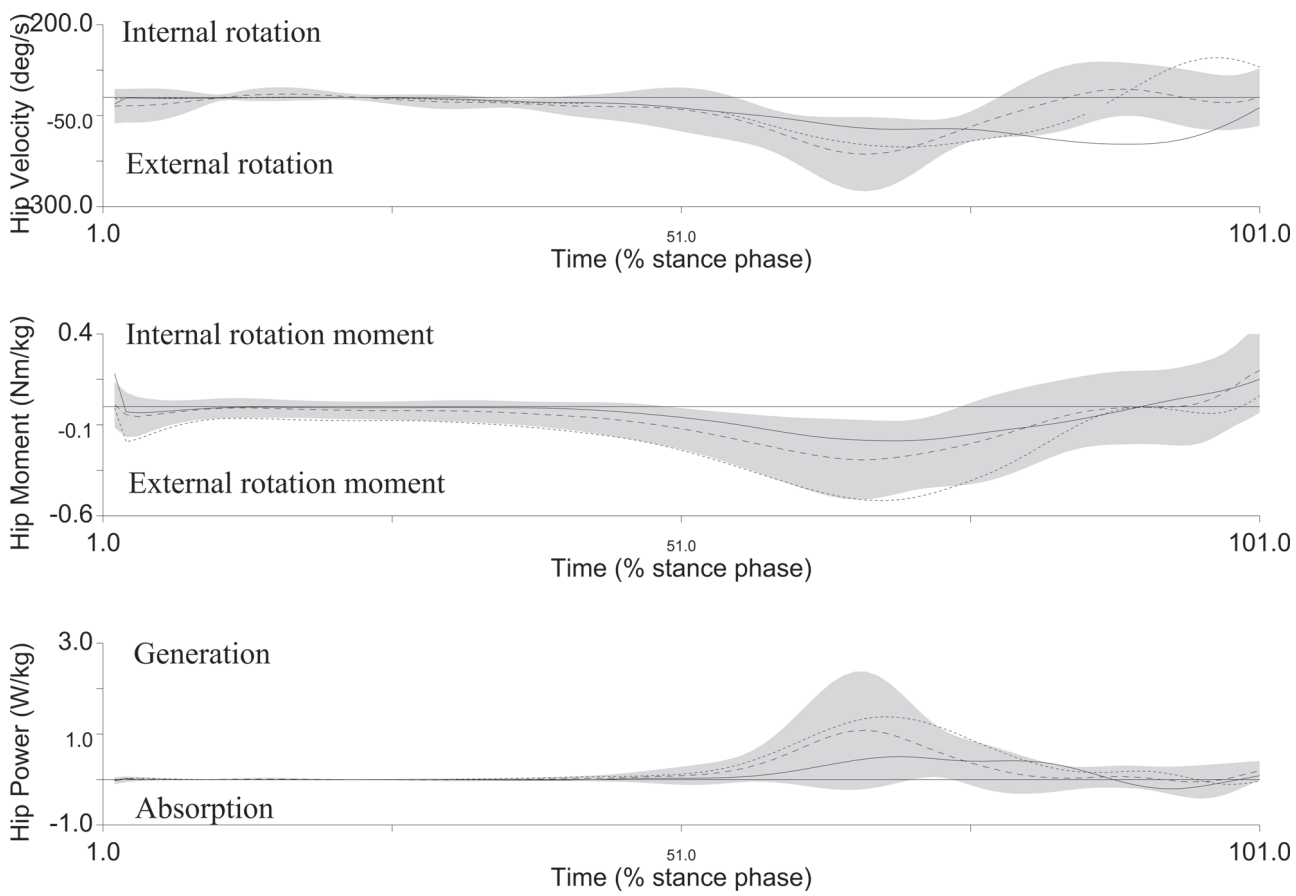

Figure 3. Mean of hip angular velocity, net hip moment of force and net hip joint power in the transversal plane during the relative times of the three $\left(0^{\circ}, 45^{\circ}\right.$ and $\left.90^{\circ}\right)$ stance positions $(N=10)$. The solid line represents the mean during $0^{\circ}$, the dashed line during the $45^{\circ}$ stance position and the dotted line during the $90^{\circ}$ stance position. The solid area represents the standard deviation from the $45^{\circ}$ curve. 
tremities during the roundhouse kick. Nonetheless, the results in the sagittal plane show an insignificant trend in which the generated power increases dependent on the progressively more lateral stance position. However, it is necessary to be aware of the fact that the net moments of force of the internal/external rotation and abduction/adduction in the knee are mainly created by the passive joint moments of force, not by the activity of muscles (Zatsiorsky, 2002). In addition, as shown in Table 1, the ankle joint generated only minimal power in the transversal and frontal planes. From a practical perspective, coaches should not only take into consideration flexion-extension at the knee and ankle joints, but also flexion-extension, internal-external rotation and adduction-abduction at the hip joints so that athletes' muscle power training will be oriented specifically.

From a methodological point of view, this study is further restricted by the fact that the retro-reflective markers move due to the effect of inertia, deformation and movement of the skin to which they are attached against the bones. This movement creates artifacts that subsequently affect the estimate of the skeletal system. The error caused by the movement of skin is considered to be the largest source of the resultant error when analyzing human motion by means of optoelectronic stereophotogrammetry (Leardini, Chiari, Croce, \& Cappozzo, 2005). Nonetheless, one characteristic of taekwondo athletes that has been noted is their preference for lower weight in order to gain a competitive advantage (Tsai, Ko, Chang, Chou, \& Fang, 2011). This could result in lower skin movement, decreasing the resultant error when human motion analysis is carried out. Moreover, we reduced the inaccuracies of optoelectronic stereophotogrammetry by using clusters of four markers that were placed distally on the segments of the lower extremities (Manal, McClay, Stanhope, Richards, \& Galinat, 2000). The authors of this study have thus focused on every aspect that could be controlled or improved in order to support the validity of the procedure. On the other hand, this study is only focused on the net joint power of the kicking lower extremity. Because the literature suggests that the kinematics of the kicking lower extremity are affected by the stance position particularly in the initial phase of the kick (Estevan, Jandačka, Farana, \& Falco, 2012), the swing phase of the kick was excluded from the net power analysis. Future research should also focus the analysis on the net joint powers of the supporting lower extremity during the roundhouse kick.

\section{CONCLUSION}

The stance position does not affect the magnitude of the peak foot velocity of the kicking lower extremity and the execution stance time. That is, taekwondo athletes are able to achieve similar peak foot velocity independent of their stance position. However, the stance position during the roundhouse kick in taekwondo influences the generation of the peak net hip joint power in the sagittal, frontal and transversal planes during the stance phase. The necessity to produce a higher net hip joint power in the stance phase of the roundhouse kick from the position when the feet are placed orthogonal to the target of the kick, compared with the execution of the kick from the forward or diagonal position, must be taken into account for purposes of rationalizing strength training of taekwondo athletes or for selecting the technique of the roundhouse kick. Trainers should focus their peak power training on the muscle groups that cause the extension, adduction and external rotation of the hip joint especially in the orthogonal stance position.

\section{ACKNOWLEDGMENTS}

This study was supported by the project 2012-007-001 of the Catholic University of Valencia.

\section{REFERENCES}

Charalambous, L., Irwin, G., Bezodis, I. N., \& Kerwin, D. (2012). Lower limb joint kinetics and ankle joint stiffness in the sprint start push-off. Journal of Sports Sciences, 30(1), 1-9.

Cohen, J. (1962). The statistical power of abnormal-social psychological research: A review. Journal of $A b$ normal Social Psychology, 63, 145-153.

Cohen, J. (1973). Eta-squared and partial eta-squared in fixed factor Anova designs. Educational and Psychological Measurement, 33, 107-112.

Cohen, J. (1988). Statistical power analysis for the behavioral sciences. Hillsdale, NJ: Erlbaum.

Estevan, I., Falco, C., \& Jandačka, D. (2011). Mechanical analysis of roundhouse kick according to the stance position. A pilot study. Portuguese Journal of Sport Sciences, 11, 215-218.

Estevan, I., Jandačka, D., Farana, R., \& Falco, C. (2012). Kinematic analysis of a roundhouse kick according to the stance position. In E. J. Bradsha, A., Burnett, \& P. A., Heme (Eds.), eProceedings of the 30th Conference of the International Society of Biomechanics in Sports (pp. 189-192). Melbourne: Australian Catholic University.

Estevan, I., Jandačka, D., \& Falco, C. (2013). Effect of stance position on kick performance in taekwondo. Journal of Sport Sciences, 31(16), 1815-1822. doi: 10.1080/02640414.2013.803590.

Falco, C., Alvarez, O., Castillo, I., Estevan, I., Martos, J., Mugarra, F., \& Iradi, A. (2009). Influence of the 
distance in a roundhouse kick's execution time and impact force in Taekwondo. Journal of Biomechanics, 42, 242-248.

Grood, E., \& Suntay, W. (1983). A joint coordinate system for the clinical description of three-dimensional motions: application to the knee. Journal of Biomechanical Engineering, 105, 136-144.

Gulledge, J. K., \& Dapena, J. A. (2008). Comparison of the reverse and power punches in oriental martial arts. Journal of Sports Sciences, 26, 189-196.

Hamill, J., \& Selbie, S. (2004). Three-dimensional kinetics. In G. E. Robertson, G. E. Caldwell, J. Hamill, G. Kamen, \& S. Whittlesey (Eds.), Research methods in biomechanics (pp. 145-162). Champaign, IL: Human Kinetics.

Hanavan, E. P. (1964). Mathematical model of the human body. Ohio, USA: Wright-Patterson Air Force Base.

Hopkins, W. G. (2000). Measures of reliability in sports medicine and science. Sports Medicine, 30, 1-15.

Kim, J. W., Kwon, M. S., Yenuga, S. S., \& Kwon, Y. H. (2010). The effects of target distance on pivot hip, trunk, pelvis, and kicking leg kinematics in Taekwondo round house kick. Sports Biomechanics, 9, 98-114.

Kim, Y. K., Kim, Y. H., \& Im, S. J. (2011). Inter-joint coordination in producing kicking velocity of Taekwondo kicks. Journal of Sports Science and Medicine, 10, 31-38.

Kraemer, W. J., \& Newton, R. U. (2000). Training for muscular power. Scientific Principles of Sport Rehabilitation, 11, 341-368.

Leardini, A., Chiari, L., Croce, U. D., \& Cappozzo, A. (2005). Human movement analysis using stereophotogrammetry: Part 3. Soft tissue artifact assessment and compensation. Gait \& Posture, 21, 212-225.

Manal, K., McClay, I., Stanhope, S., Richards, J., \& Galinat, B. (2000). Comparison of surface mounted markers and attachment methods in estimating tibial rotations during walking: An in vivo study. Gait \& Posture, 11, 38-45.

Melhim, A. F. (2001). Aerobic and anaerobic power responses to the practice of taekwon-do. British Journal of Sports Medicine, 35, 231-234.

Mero, A. (1988). Force-time characteristics and running velocity of male sprinters during the acceleration phase of sprinting. Research Quarterly for Exercise and Sport, 59, 94-98.

Mero, A., Kuitunen, S., Harland, M., Kyrolainen, H., \& Komi, P. V. (2006). Effects of muscle-tendon length on joint moment and power. Journal of Sports Sciences, 24, 165-173.

O’Sullivan, D., Chung, C., Lee, K., Kim, E., Kang, S., Kim, T., \& Shin, I. (2009). Measurement and comparison of Taekwondo and Yongmudo turning kick impact force for two target heights. Journal of Sports Science and Medicine, 8, 13-16.
Pieter, F., \& Pieter, W. (1995). Speed and force in selected taekwondo techniques. Biology of Sport, 12, 257-266.

Pozo, J., Bastien, G., \& Dierick, F. (2011). Execution time, kinetics, and kinematics of the mae-geri kick: Comparison of national and international standard karate athletes. Journal of Sports Sciences, 29, 15531561.

Tsai, H. L., Ko, M. H., Chang, C. K., Chou, K. M., \& Fang, S. H. (2011). Impact of intense training and rapid weight changes on salivary parameters in elite female taekwondo athletes. Scandinavian Journal of Medicine \& Science in Sports, 21, 758-764.

Zatsiorsky, V. M. (2002). Kinetics of human motion. Champaign, IL: Human Kinetics.

\section{VLIV POČÁTEČNÍ STOJNÉ POLOHY NA KINE- TIKU DOLNÍCH KONČETIN PŘI OBLOUKOVÉM KOPU V TAEKWONDU \\ (Souhrn anglického textu)}

VÝCHODISKA: Pro dosažení odpovídající sportovní výkonnosti musí taekwondisté optimalizovat polohu nohou na podložce $\mathrm{v}$ počáteční stojné poloze.

CÍLE: Cílem této studie je porovnat generovaný výkon kloubů dolních končetin (kyčelní, kolenní a hlezenní kloub), maximální rychlost nohy útočné dolní končetiny a realizační dobu stojné fáze $\mathrm{v}$ závislosti na třech počátečních stojných polohách (př́imá " 0 ”", diagonální " $45^{\circ}$ ”, kolmá “90") při obloukovém kopu v taekwondu.

METODIKA: Této studie se zúčastnilo deset taekwondistů. Jejich zkušenost s vykonáváním taekwonda se pohybovala $\mathrm{v}$ průměru se směrodatnou odchylkou 13,8 \pm 5,8 let. Při každém obloukovém kopu byl proveden záznam kinematiky a kinetiky. Byla stanovena maximální rychlost nohy útočné dolní končetiny a realizační doba stojné fáze. Výstupní výkon kloubů dolních končetin byl stanoven pomocí metody inverzní dynamiky. Následně byla stanovena maxima výstupních výkonů kloubů dolních končetin.

VÝSLEDKY: Analýza rozptylu pro opakovaná měření ukázala signifikantní hlavní efekt počáteční stojné polohy na maximální výstupní výkon kyčelního kloubu ve všech třech rovinách. Navíc počáteční stojná poloha neovlivnila maximální rychlost nohy útočné dolní končetiny a realizační dobu stojné fáze.

ZÁVĚRY: Skutečnost, že při obloukovém kopu vedeném z polohy kdy nohy jsou v kolmé poloze vưči cíli, je nezbytné produkovat větší výstupní výkon v kyčelním kloubu, je nutno brát $v$ úvahu při racionalizaci silového tréninku a také při výběru techniky provedení obloukového kopu.

Klíčová slova: trénink výkonu, inverzní dynamika, biomechanika, stojná poloha. 